\title{
Evaluasi Klinis Pengobatan Epilepsi dengan Karbamazepin pada Anak
}

\author{
Pratiwi Andayani, Taslim S Soetomenggolo, Sri Rezeki S Hadinegoro
}

\begin{abstract}
Untuk melihat efektivitas karbamazepin, dilakukan penelitian pemakaian karbamazepin pada pasien epilepsi jenis bangkitan parsial dan umum di Bagian IKA FKUI-RSCM. Penelitian ini merupakan studi kuasi-eksperimental dengan desain pre dan post test. Karbamazepin dapat menekan bangkitan epilepsi pada $20(86,9 \%)$ kasus. Sebelas di antaranya adalah epilepsi jenis bangkitan umum, dan 9 kasus lainnya epilepsi jenis bangkitan parsial. Gambaran EEG sebagian besar kasus adalah abnormal. Dosis rerata karbamazepin yang dapat memberantas bangkitan epilepsi 15,95mg/kgBB/hari. Kadar terendah karbamazepin plasma yang dapat menekan bangkitan epilepsi adalah 1,215ug/ $\mathrm{mL}$, dengan kadar rerata 5,74ug/mL. Kebanyakan efek samping yang terjadi ringan dan tidak menetap. Efek samping yang berat yaitu sindrom Steven Johnson terdapat pada 3 kasus.
\end{abstract}

Kata kunci: epilepsi, karbamazepin, kadar karbamazepin darah

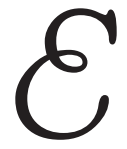

pilepsi pada anak mempunyai angka kejadian cukup tinggi. Sebagian besar epilepsi pada orang dewasa mengalami serangan awal pada usia dini. ${ }^{1}$ Insidens epilepsi pada anak 20-70 per 100000 per tahun, ${ }^{1,2}$ dengan prevalens $500-2000$ per 100000. ${ }^{1}$ Pengobatan epilepsi dengan fenobarbital tidak lagi merupakan pilihan pertama di luar negeri, walaupun cukup efektif, aman, dan tidak mahal, ${ }^{3-5,8,9}$ tetapi mempunyai efek samping mengantuk, gangguan tidur, bertambah agresif, hiperaktif, ${ }^{4,6,10}$ gangguan tingkah laku, dan penurunan kecerdasan. ${ }^{4}$ Efek samping dan reaksi toksik fenobarbital pada anak tercatat mencapai $40 \% .^{11}$

Pada saat ini karbamazepin merupakan OAE

Staf Bagian Ilmu Kesehatan Anak RS Fatmawati (Dr. Pratiwi Andayani, Sp.A.), Staf Subbagian Neurologi Anak. Bagian Ilmu Kesehatan Anak FKUI-RSCM (Prof. Dr. Taslim S Soetomenggolo, Sp.A(K)) dan Kepala Subbagian Infeksi dan Penyakit Tropis. Bagian Ilmu Kesehatan Anak FKUI-RSCM (Prof. DR. Dr. Sri Rezeki S Hadinegoro, Sp.A(K)).

Alamat korespondensi:

Dr. Pratiwi Andayani, Sp.A.

Staf Bagian Ilmu Kesehatan Anak RS Fatmawati. Jl. Fatmawati, Jakarta. Tel. 021-766 0552 / 7501524. Fax. 7690123. utama di Amerika Serikat, ${ }^{6,12}$ karena terbukti efektif menekan semua jenis bangkitan epilepsi kecuali pada bangkitan absens dan mioklonik. ${ }^{13-15}$ Struktur kimianya mirip dengan anti depresan trisiklik, ${ }^{4}$ yang mempunyai efek perbaikan psikis. ${ }^{6}$ Karbamazepin dilaporkan lebih baik menekan bangkitan kejang daripada fenobarbital, walaupun secara statistik tidak bermakna. ${ }^{13}$ Obat ini sangat efektif, tetapi memerlukan pemantauan konsentrasi obat dalam darah. ${ }^{16}$ Penelitian ini bertujuan mendapatkan obat alternatif yang efektif menekan bangkitan kejang pada epilepsi jenis bangkitan umum dan bangkitan parsial.

\section{Bahan dan Cara}

Penelitian ini merupakan studi kuasi-eksperimental dengan desain pre dan post test pada pasien baru yang didiagnosis epilepsi dan belum pernah diobati, baik yang datang ke poliklinik Subbagian Neurologi Anak RSCM atau dalam perawatan di ruang rawat inap Bagian Anak IKA FKUI-RSCM. Penelitian dilakukan selama 1 tahun. 
Seluruh pasien dengan jenis bangkitan umum dan parsial merupakan populasi target. Populasi terjangkau adalah pasien epilepsi baru yang berobat jalan dan atau dirawat di Subbagian Neurologi IKA FKUI-RSCM dalam periode penelitian, serta memenuhi kriteria penerimaan dan penolakan yang telah ditetapkan.

Kriteria penerimaan ialah pasien baru yang didiagnosis secara klinis sebagai epilepsi jenis bangkitan umum dan bangkitan parsial, baik disertai maupun tanpa kelainan otak organik, berusia 1 bulan sampai 15 tahun, belum pernah mendapat karbamazepin atau OAE lain sebelumnya. Pasien dengan penyakit hati dan atau dengan kelainan fungsi hati, serta menderita leukopenia atau netropenia tidak diikutsertakan dalam penelitian.

Perkiraan besar sampel dihitung berdasarkan proporsi pasien yang bebas serangan kejang setelah terapi 3 bulan. Proporsi subyek yang bebas bangkitan kejang (p) 0,75 , q adalah 0,25 , dan penyimpangan yang masih diterima (L) adalah $0,2 \%$. Drop out diperkirakan terjadi sebesar 10\%, sehingga sampel adalah 20 .

Persetujuan tertulis diminta kepada orangtua pasien sebelum penelitian dimulai. Data diambil dari kuesioner dan laporan ibu melalui telepon. Pemeriksaan fisis rutin dikerjakan pada setiap pasien. Pemeriksaan hemoglobin $(\mathrm{Hb})$, leukosit, trombosit, albumin, globulin, serum glutamic oksaloasetic transaminase (SGOT), serum glutamic-pyruvic transaminase (SGPT), dan fosfatase alkali dilakukan di laboratorium Bagian IKA FKUI-RSCM. Pemeriksaan EEG dilakukan di Subbagian Neurologi Anak RSCM.

Karbamazepin diberikan per oral dalam bentuk sirup, memakai alat suntik sebagai takaran. Dosis awal $10 \mathrm{mg} / \mathrm{kgBB} /$ hari dalam dosis terbagi, dipertahankan selama 2 minggu untuk mencapai keadaan steadystate. Respons obat dinilai dari catatan harian yang diisi ibu, berisi frekuensi, waktu terjadi, dan gambaran bangkitan kejang. Dosis obat dinaikkan bila masih timbul bangkitan kejang pada pasien yang minum karbamazepin secara teratur, dengan dosis benar. Edukasi diberikan pada pasien dengan kepatuhan minum obat yang buruk dan takaran obat yang salah. Kenaikan dosis dilakukan bertahap, yaitu $5 \mathrm{mg} / \mathrm{kgBB}$ setiap 2 minggu hingga mencapai dosis maksimal $40 \mathrm{mg} / \mathrm{kgBB} / \mathrm{hari}$ atau kadar karbamazepin maksimal dalam darah $12 \mathrm{ug} / \mathrm{mL}$.

Pasien dievaluasi setiap 2 minggu di poliklinik Subbagian Neurologi IKA FKUI-RSCM. Pada 2 minggu pertama dan setiap kenaikan dosis obat, diambil $5 \mathrm{~mL}$ darah beku untuk pemeriksaan kadar karbamazepin dalam darah. Kadar karbamazepin diperiksa di laboratorium Bagian Farmakologi FKUI dengan teknik high performance liquid chromatography (HPLC). Bila bangkitan kejang dapat diatasi, kadar karbamazepin dalam darah diperiksa sekali lagi pada akhir bulan ke-2 pengamatan. Leukosit dipantau tiap 2 minggu dalam 1 bulan pertama, dan pada akhir minggu ke-3. Pemberian karbamazepin dihentikan bila jumlah leukosit mencapai kurang dari 2500/uL. ${ }^{17}$ Timbulnya efek samping diawasi selama masa penelitian, dan kepada orangtua diterangkan kemungkinan yang dapat terjadi akibat efek samping obat. Bila timbul efek samping obat, pasien harus kembali ke rumah sakit secepatnya untuk mendapat pertolongan atau perawatan.

\section{Hasil}

Selama kurun waktu 1 Janauri 1996 sampai dengan 31 Januari 1997 dijumpai 28 orang anak penderita epilepsi baik umum maupun parsial yang berobat di poliklinik neurologi anak RS Cipto Mangunkusumo. Lima kasus tidak menyelesaikan penelitian, karena 3 kasus sindrom Stevens Johnson dan 2 kasus lainnya tidak dapat dikontrol lagi (lost to follow-up). Dua puluh delapan kasus terdiri 16 (57\%) anak lelaki dan 12 (43\%) anak perempuan.

Sebaran usia kasus yang diteliti antara 3 bulan 15 tahun. Jumlah kasus terbanyak pada kelompok usia $1-4$ tahun yaitu 10 (36\%) kasus. Sebaran jenis bangkitan epilepsi sebanding yaitu bangkitan umum 14 (50\%) kasus dan bangkitan parsial 14 (50\%) kasus. Epilepsi jenis bangkitan parsial terdiri dari bangkitan parsial sederhana $2(7,20 \%)$ kasus, bangkitan parsial kompleks $6(21,40)$ kasus, dan bangkitan parsial menjadi tonik klonik umum $6(21,40 \%)$ kasus. Epilepsi jenis bangkitan umum terdiri dari bangkitan umum tonik 7 (25\%) kasus, dan bangkitan umum tonik klonik 7 (25\%) kasus.

Dua $(7,20)$ kasus epilepsi jenis bangkitan parsial sederhana semuanya laki-laki, $6(21,40 \%)$ kasus epilepsi bangkitan parsial kompleks terdiri dari 3 orang laki-laki dan 3 orang perempuan, dan $6(21,40 \%)$ kasus epilepsi parsial menjadi tonik klonik terdiri dari lakilaki dan perempuan dengan perbandingan yang sama. Tujuh (25\%) kasus epilepsi bangkitan umum tonik, 5 kasus di antaranya laki-laki. Pada 7 (25\%) kasus epilepsi 
Tabel 1. Sebaran kasus berdasarkan gambaran EEG

\begin{tabular}{lll}
\hline Gambaran EEG & $\mathrm{n}$ & Persentase \\
\hline - Khas epilepsi & & \\
Gel. Epileptiform umum & 8 & 28,57 \\
Gel. Epileptiform umum+fokal & 3 & 10,71 \\
Gel. Epileptiform fokal & 10 & 35,72 \\
Tidak khas epilepsi & & \\
Hipoaktifitas & 3 & 10,71 \\
Normal & 4 & 14,29 \\
Total & 28 & 100,00 \\
\hline
\end{tabular}

bangkitan umum tonik klonik, 4 di antaranya perempuan.

Sebaran $\mathrm{Hb}$ kasus 9,00g/dl-14,70g/dL dengan nilai median $11,2 \mathrm{~g} / \mathrm{dL}$, leukosit 3900 peruL-17500 per uL dengan nilai median 8600 per uL, trombosit 257000 per uL-566000 per uL dengan nilai median 340000 per uL. Nilai rerata SGOT adalah $22,15 \mathrm{mu} / \mathrm{mL}$, SGPT $14,07 \mathrm{mu} / \mathrm{ml}$, dan albumin $4,46 \mathrm{mu} / \mathrm{ml}$.

Gambaran EEG 28 kasus yang diteliti terdapat 4 normal dan 24 abnormal. Pada 24 kasus dengan EEG abnormal $10(35,72 \%)$ kasus mempunyai gambaran gelombang epileptoform fokal, $8(28,57 \%)$ kasus gelombang epileptiform umum, 3 (10,71\%) kasus gelombang campuran epileptiform umum dengan fokal, dan $3(10,71)$ kasus lainnya gambaran hipoaktivitas (Tabel 1).

Berdasarkan etiologi, 25 (89,28\%) kasus digolongkan epilepsi idiopatik, dan 3 (10,72\%) kasus epilepsi simtomatik. Sebagian kasus disertai kelainan penyerta yaitu atrofi otak pada 1 kasus, retardasi mental 5 kasus, dan 1 kasus talasemia mayor. Dua kasus di antara 5 kasus retardasi mental dengan mikrosefal. Pada 3 kasus epilepsi simtomatik, 2 kasus disebabkan ensefalitis dan infeksi CMV pada kehamilan, dan 1 kasus talasemia.

Empat belas (14/28) kasus mempunyai riwayat kejang demam sebelumnya. Delapan kasus di antaranya epilepsi jenis bangkitan umum dan 6 kasus lainnya epilepsi jenis bangkitan parsial.

Pada 23 kasus yang diteliti, bangkitan epilepsi hilang dengan sempurna pada 16 kasus. Setelah dikelompokkan, 20 (86,9\%) kasus mempunyai hasil baik, cukup pada $1(4,3 \%)$ kasus, dan gagal pada 2 $(8,8 \%)$ kasus (Tabel 2). Dua puluh tiga kasus terdiri dari 13 kasus epilepsi dengan bangkitan umum dan 10 kasus epilepsi bangkitan parsial. Kegagalan terapi
Tabel 2. Sebaran hasil pengobatan berdasarkan frekuensi bangkitan epilepsi

\begin{tabular}{lll}
\hline Hasil pengobatan & Jumlah & Persentase \\
\hline Baik & 20 & 86,95 \\
Cukup & 1 & 4,35 \\
Gagal & 2 & 8,70 \\
Total & 23 & 100,00 \\
\end{tabular}

hanya pada $2(2 / 13)$ kasus epilepsi jenis bangkitan umum, sebaliknya pada epilepsi jenis bangkitan parsial tidak terdapat kegagalan terapi. Pada kelompok epilepsi jenis bangkitan umum, 11 (11/13) kasus mempunyai hasil pengobatan yang baik. Pada kelompok epilepsi jenis bangkitan parsial $9(9 / 10)$ kasus mengalami hasil yang baik.

Berdasarkan etiologi, 2 kasus kegagalan terapi merupakan epilepsi idiopatik, sedangkan 3 kasus epilepsi simtomatik semuanya menunjukkan hasil baik. Pada 3 (11,5\%) kasus mengalami sindrom Stevens Johnson, 2 kasus timbul gejala pada minggu ke-2 dan 1 kasus pada minggu ke-3. Efek samping lainnya ringan yaitu perasaan mengantuk 2 orang, sakit kepala 3 orang, dan eritema 1 orang. Tiga kasus mengalami perbaikan tingkah laku dan perasaan (Tabel 3).

Pada bulan pertama terdapat 2 kasus dan bulan ketiga terdapat 1 kasus mengalami leukopenia, tetapi tidak perlu menghentikan pengobatan.

Dosis awal karbamazepin adalah $10 \mathrm{mg} / \mathrm{kgBB}$, dan selanjutnya dinaikkan bila timbul bangkitan epilepsi.

Tabel 3. Efek samping karbamazepin pada pasien epilepsi

\begin{tabular}{|c|c|c|}
\hline Efek samping & $\mathrm{n}$ & Proporsi \\
\hline Perasaan mengantuk & 2 & $2 / 26$ \\
\hline Sakit kepala* & 3 & $3 / 15$ \\
\hline Sindrom Stevens Johnson & 3 & $3 / 26$ \\
\hline Eritema & 1 & $1 / 26$ \\
\hline Tingkah laku: Perbaikan** & 3 & $3 / 15$ \\
\hline Perburukan & 0 & $0 / 15$ \\
\hline Tidak ada keluhan & 4 & $14 / 26$ \\
\hline
\end{tabular}

* Hanya anak besar yang sudah dapat memberi keterangan

** Perbaikan aktivitas sehari-hari: makan, berpakaian, mandi, belajar, dan bersekolah 
Dua (2/23) kasus di antaranya mengalami kegagalan pengobatan, sehingga rerata kadar karbamazepin yang dapat menekan bangkitan epilepsi pada 21 kasus adalah $15,5 \mathrm{mg} / \mathrm{kgBB}$.

Pada 23 kasus yang diberikan karbamazepin dengan dosis awal $10 \mathrm{mg} / \mathrm{kgBB}$; kadar rerata karbamazepin plasma setelah 2 minggu 3,220ug/mL. Pada akhir penelitian 21 kasus dengan dosis rerata karbamazepin $15,5 \mathrm{mg} / \mathrm{kgBB}$ mencapai kadar rerata karbamazepin plasma 5,74ug/mL. Dua kasus gagal pengobatan, pada dosis karbamazepin $40 \mathrm{mg} / \mathrm{kgBB}$ mempunyai kadar karbamazepin plasma 10,610ug/ $\mathrm{mL}$ dan $11,454 \mathrm{ug} / \mathrm{mL}$.

\section{Pembahasan}

Rasio jenis kelamin anak epilepsi, lelaki sedikit lebih banyak dibanding anak perempuan yaitu 1,3 hal ini sesuai dengan penelitian Shorvon $\mathrm{dkk}^{2}$ yang mendapatkan rasio 1,1 dan Cowan dkk. ${ }^{18}$ 1,5.

Sebaran usia kasus yang diteliti sesuai dengan insidens epilepsi yang berubah-ubah menurut usia, ${ }^{1}$ yaitu insidens tertinggi pada usia anak dini, mencapai nadirnya pada usia dewasa dini, dan naik kembali pada usia tua. ${ }^{2}$ Bangkitan epilepsi jarang dijumpai pada usia bulan-bulan pertama, dan lebih sering antara usia 4 bulan-4 tahun, kemudian frekuensinya menurun sampai remaja. ${ }^{19}$ Bangkitan kejang pada bayi prematur lebih jarang terjadi dibanding bayi cukup umur, karena sistem saraf bayi prematur belum berkembang. Hal ini menunjukkan faktor usia dan perkembangan ikut mempengaruhi terjadinya epilepsi pada anak. ${ }^{20}$

Pada kelompok epilepsi jenis bangkitan umum tidak didapatkan pasien epilepsi jenis bangkitan umum klonik, sedangkan jumlah pasien epilepsi jenis umum tonik dan jenis umum tonik-klonik sebanding. Hasil penelitian ini tidak sesuai dengan penelitian Menkes ${ }^{21}$ dan Cowan dkk. ${ }^{18}$ yang mendapatkan epilepsi jenis bangkitan umum tonik-klonik merupakan manifestasi epilepsi yang paling sering terdapat pada masa anak. Lebih kurang 70\% bangkitan epilepsi pada anak merupakan bangkitan umum tonik-klonik. ${ }^{22}$

Nilai rerata $\mathrm{Hb}$ dan leukosit bervariasi, sedangkan nilai laboratorium lainnya menurut Nicholson dan Pesce $^{23}$ masih dalam kisaran nilai normal. Terdapat 1 kasus dengan leukosit $17500 / \mathrm{uL}$, keadaan ini disebabkan pasien menderita ISPA. Satu kasus lainnya dengan leukosit 3900 per uL adalah penderita talasemia $ß$ dengan hipersplenisme. ${ }^{24}$

Bila dilihat dari jenis bangkitan epilepsinya, gambaran EEG normal paling banyak terdapat pada epilepsi jenis bangkitan umum. Hal ini menggambarkan tidak semua gangguan fungsi otak dapat tercermin pada rekaman EEG. Gambaran EEG normal dapat dijumpai pada anak dengan kelainan otak, dan sebaliknya gambaran EEG abnormal dapat dijumpai pada anak normal. ${ }^{21,25}$ Diperkirakan pada $10 \%$ pasien epilepsi mempunyai gambaran EEG normal. ${ }^{26}$

Sebagian besar kasus (89,28\%) digolongkan pada epilepsi idiopatik. Pada umumnya penyebab bangkitan kejang sesuai dengan awitan bangkitan kejang pertama, walaupun sebagian besar epilepsi merupakan epilepsi idiopatik yang tidak diketahui penyebabnya. Cowan dkk. ${ }^{18}$ mendapatkan $70 \%$ kasus adalah idiopatik, sedangkan sisanya disebabkan faktor perinatal, infeksi otak, dan trauma. Pada epilepsi idiopatik terdapat kecenderungan penurunan disritmia serebral secara genetik. ${ }^{27}$ Satu kasus epilepsi bangkitan parsial kompleks adalah talasemia mayor yang memerlukan transfusi serial. Hal ini menurut Wasi $\mathrm{dkk}^{28}$ dapat menyebabkan terjadinya suatu sindrom pada talasemia dengan manifestasi perdarahan intraserebral, yang dikemudian hari dapat menyebabkan terjadinya epilepsi. Terdapat beberapa kelompok orang yang mempunyai risiko tinggi untuk terjadinya epilepsi; antara lain orang yang menderita kelainan serebrovaskular meliputi hemisfer serebri dan ensefalitis terutama yang disebabkan oleh virus. ${ }^{29,30}$

Riwayat kejang demam terdapat pada 50\% kasus. Sebagian kecil anak dengan riwayat kejang demam mempunyai risiko menderita epilepsi di kemudian hari. Sebanyak 3\% di antara anak dengan kejang demam mengalami setidak-tidaknya 1 kali kejang tanpa demam. ${ }^{27}$ Terdapat 3 faktor risiko terjadinya epilepsi pada kejang demam yaitu (1) adanya kelainan neurologis sebelum kejang demam pertama, (2) lama kejang lebih dari 15 menit atau kejang fokal, atau adanya defisit neurologis baik permanen atau tidak, (3) terdapat riwayat kejang tanpa demam dalam keluarga. Bila terdapat 2 dari 3 faktor risiko tersebut, maka risiko menjadi epilepsi sekitar 13\% dan bila hanya terdapat 1 atau tidak sama sekali faktor tersebut maka risikonya hanya 2-3\% saja. ${ }^{11}$ Lumbantobing $^{31}$ pada penelitiannya di Bagian IKA FKUI-RSCM mendapatkan 5 pasien dari 83 kasus (6\%) kejang demam yang kemudian menderita epilepsi.

Keberhasilan karbamazepin menekan bangkitan 
epilepsi pada penelitian ini mencapai 86,9\%. Angka ini lebih tinggi dari yang dilaporkan Scheffner dkk, ${ }^{32}$ yaitu efektif untuk sepertiga sampai setengah kasus epilepsi jenis bangkitan parsial dan umum tonik-klonik pada anak dan dewasa. Shorvon $\mathrm{dkk}^{33}$ dan Schmidt $\mathrm{dkk}^{34}$ mendapatkan efektivitas karbamazepin sesuai dengan hasil penelitian yaitu $62-88 \%$, demikian pula Okuno $\mathrm{dkk}^{35}$ mendapatkan $74 \%$.

Tiga kasus mengalami leukopenia selama pengobatan. Umumnya OAE dapat menyebabkan leukopenia. Pada awal terapi karbamazepin, 10\% kasus mengalami leukopenia ringan dan akan membaik dalam 4 bulan terapi. ${ }^{12}$ Keadaan ini merupakan suatu dilema, terutama bila OAE tersebut efektif dalam menekan bangkitan epilepsi. OAE harus dihentikan dan dilakukan pemeriksaan sumsum tulang bila jumlah obsolut sel PMN menurun kurang dari 1000/uL.

Dosis efektif $15,5 \mathrm{mg} / \mathrm{kgBB}$ terdapat dalam kisaran dosis obat yang dianjurkan untuk mencapai laju absorpsi yang optimal, yaitu $14-16 \mathrm{mg} / \mathrm{kgBB} .{ }^{36}$ Peneliti lain menganjurkan kisaran dosis yang bervariasi, yaitu $10-25 \mathrm{mg} / \mathrm{kg} / \mathrm{hari},{ }^{21} 30 \mathrm{mg} / \mathrm{kgBB},{ }^{15}$ atau $40 \mathrm{mg} / \mathrm{kgBB} .{ }^{16}$ Beragamnya pendapat tentang dosis karbamazepin disebabkan hasil penelitian yang berbeda-beda, absorpsi karbamazepin yang ireguler akibat laju disolusi dalam cairan gastrointestinal yang lambat, dan sifat antikolinergis obat dapat merubah waktu transit gastrointestinal. ${ }^{4}$

Rerata kadar karbamazepin plasma 5,74ug/mL termasuk dalam kisaran kadar terapi menurut Menkes ${ }^{21}$ yaitu 4-12 metode HPLC seperti pada penelitian ini. Metode EMIT menghasilkan nilai sedikit lebih tinggi karena terjadi reaksi silang antara antibodi spesifik karbamazepin dengan metabolit karbamazepin, terutama $\mathrm{ug} / \mathrm{mL}$, tetapi masih di bawah dari yang didapatkan Johnston dkk ${ }^{35}$ dan Gilman ${ }^{12}$ yaitu 6-12ug/ $\mathrm{mL}$. Hal ini disebabkan karbamazepin epoksid, sebaliknya pada metode HPLC reaksi silang ini tidak terjadi. ${ }^{37}$ Namun demikian Ashy $\mathrm{dkk}^{38}$ menunjukkan bahwa metode immunoassay dalam hal ini fluorescence polarization immunoassay (FPIA) dan EMIT mempunyai akurasi yang cukup baik dan sebanding dengan metode HPLC.

Keterbatasan penelitian ini adalah jangka waktu penelitian yang pendek sehingga tidak semua efek smping dapat dipantau.

Dapat disimpulkan bahwa efektivitas karbamazepin menekan bangkitan epilepsi 86,9\%. Pada epilepsi jenis bangkitan umum hasil baik pada $11(11 / 13)$ kasus, dan jenis bangkitan parsial hasil baik pada 9 (9/10) kasus. Efek samping obat yang terjadi berupa sindrom Stevens Johnson terdapat pada 3 kasus (11,54\%), efek samping lainnya ringan dan tidak menetap. Dosis rerata karbamazepin yang dapat memberantas bangkitan epilepsi adalah $15,95 \mathrm{mg} / \mathrm{kgBB} / \mathrm{hari}$, dan kadar rerata karbamazepin plasma yang dapat memberantas kejang adalah $5,74 \mathrm{ug} / \mathrm{mL}$.

\section{Daftar Pustaka}

1. Shorvon SD. Epilepsi, a general practise perspective; edisi 1. Basel: Ciba Geigy, 1988; 2-5.

2. Shorvon SD. Epidemiology, classification, natural history and genetics of epilepsy. Lancet 1990; 336:93-6.

3. Brodie MJ. Established anticonvulsants and treatment of refractory epilepsy. Lancet 1990; 336:350-4.

4. Yaffe SJ. Pediatric pharmacology. Therapeutic principles in practice. New York: Grune \& Stratton 1980; 200-2.

5. Millichap JG. Progress in pediatric neurology. Chicagop: pediatric neurology briefs 1991; 94-107.

6. Utama H, Gan VHS. Anti konvulsi. Dalam: Gan S penyunting. Farmakologi dan terapi. Edisi ke-3. Jakarta: Bagian Farmakologi Fakultas Kedokteran Universitas Indonesia, 1991; 142-51.

7. Ismael S. Efficacy of phenobarbital in controlling epilepsy in children. Pediatr Indones 1990; 30:97-110.

8. Walson PD, Powell JR, Mimaki T. Anticonvulsant usage. Dalam: Walson PD, Powell JR, Mimaki T, penyunting. Pediatric pharmacology therapeutic principles in practice. New York: Grune and Stratton, 1980:196-216.

9. Prichard JW, Ransom BR. Phenobarbital, mechanisms of action. Dalam: Levy R, mattson R, Meldrum B, penyunting. Antiepileptic drug; edisi ke-3. New York: Raven Press, 1989; 267-77.

10. Gallagher BB. Phenobarbital. Dalam: Resor SR, Kutt $\mathrm{H}$, penyunting. The medical treatment of epilepsy. New York: Marcel Dekker, 1992; 357-62.

11. Freeman JM. Frebile seizure: a consensus of their significance, evaluation, and treatment. Pediatrics 1980; 66:1009.

12. Rall TW, Schleifer LS. Drugs effective in the therapy of the epilepsies. Dalam: Gilman AG, Goodman LS, Gilman A, penyunting. The pharmacological basis of therapeutics. Edisi-8. New York: Mc Graw-Hill, 1992; 447-9.

13. Mitchell WG, Chavez JM. Carbamazepin versus phenobarbital for partial onset seizures in children. Epilepsia 1987; 28:5-60.

14. Dodson WE. Carbamazepin efficacy and utilization in children. Epilepsia 1987; 28:S17-24.

15. Lazuardi S. Pengobatan epilepsi. Disampaikan pada simposium epilepsi pada anak. Jakarta 25 April 1992.

16. Gilman JT. Carbamazepin dosing for pediatric seizure disorders; thehighs and lows. Pediatrics 1991; 25:1109-12. 
Sari Pediatri, Vol. 2, No. 3, Desember 2000

17. Pellock JM. Carbamazepin side effects in children and adults. Epilepsia 1987; 28:S64-70.

18. Cowan LD, Bodensteiner JB, Leviton A, Doherty L. Prevalence of the epilepsies in children and adolescents. Epilepsia 1989; 30:94-106.

19. Tsuboi T, Okada S. The genetics of epilepsy. Dalam: Sakai $T$, Tsuboi $T$, penyunting. Genetic aspects of human behavious. Tokyo: Igaku-Shoin, 1985; 113-27.

20. Lumbantobing SM. Etiologi dan faal sakitan epilepsi. Disampaikan dalam simposium epilepsi pada anak, Jakarta 25 April 1992.

21. Menkes JH. Paroxysmal disorders. Dalam: Menkes JH, penyunting. Textbook of child neurology. Philadelphia: Lea \& Febiger, 1989; 602-74.

22. Chevrie JJ, Aicardi J. Convulsive disorders in the first year of life, persistance of epileptif seizures. Epilepsia 1979; 20:643-9.

23. Nicholson JF, Pesce MA. Laboratory medicine and reference tables. Dalam: Nelson WE, Behrman RE, Kliegman RM, Arvin AM, penyunting. Nelson textbook of pediatrics, edisi ke-15. Philadelphia: WB Saunders, 1996; 2031-84.

24. Anderson DM, Patwell JM, Plaut K, McCullough K, penyunting. Dorland's illustrated, medical dictionary, edisi ke-27. Philadelphia: WB Saunders, 1988; 916.

25. Aicardi J. Epilepsy and other seizure disorders. Dalam: Aicardi J, Bax M, Gillberg C, Ogier H, penyunting. Diseases of the nervous system in childhood. New York: Mac Keith Press, 1992; 911-82.

26. Soetomenggolo TS. Pemeriksaan penunjang pada epilepsi. Disampaikan dalam simposium epilepsi pada anak, Jakarta 25 April 1992.

27. Hauser WA, Ramirez-Lassepas M, Rosenstein R. Risk for seizures and epilepsy following cerebrovascular insults. Epilepsia 1984; 25:666.

28. Temu karya nasional anemia. Jakarta 1993. (Dikutip dari Kodyat BA. Masalah gizi masyarakat dan program penanggulangannya. Dalam: Samsudin, Nasa SS, Sjarif
DR, penyunting. Masalah gizi ganda dan tumbuh kembang anak. Naskah lengkap pendidikan kedokteran berkelanjutan Ilmu Kesehatan Anak FKUI XXXV; 11 12 Agustus 1995, Jakarta. Jakarta : Balai Penerbit FKUI, 1995).

29. Honig GR. Hemoglobin disorders. Dalam: Nelson WE, Behrman RE, Kiegman RM, Arvin AM. Nelson textbook of pediatric, edisi ke-15. Philadelphia: WB Saunders, 1996; 1396-1405.

30. Wasi P, Na- Nakorn S, Pootrakul P dkk. A syndrome of hypertension, convulsion and cerebral haemorrhage in thalassemic patients after multiple blood transfussions. Lancet, 1978; 16:602-4.

31. Annegers JF, Hauser WA, Beghi E, Nicolosi A, Kurland LT. The risk of unprovoked seizures after encephalitis and meningitis. Neurology 1988; 38:1407-10.

32. Kurtz Z, Tookey P, Ross E. The epidemiology of epilepsy in childhood. Dalam: Ross, Chadwick, Crawford dkk. Epilepsy in young people. New York: John Wiley \& sons, 1987; 13-21. (Dikutip dari Passat J. Epidemiology epilepsi. Disampaikan dalam simposium epilepsi pada anak, Jakarta, 25 April 1992).

33. Lumbantobing SM. Epilepsi, beberapa segi klinik. Disertasi. Jakarta: FKUI 1975.

34. Scheffner D, Schiefer I. The treatment of epileptic children with carbamazepine. Follow up studies of clinical course and EEG. Epilepsia 1972; 13:819-28.

35. Shorvon SD, Chadwick D, Galbraith AW, Reynold EH. One drug for epilepsy. Br Med J 1978; 1:474-6.

36. Reynolds EH. Mental effect of antiepileptic medication: a review. Epilepsia 1983; 24:S85-95.

37. Schmidt D, Tsai JJ, Janz D. Generalized tonic-clonic seizures in patients with complex-partial seizures: natural history and prognostic relevance. Epilepsia 1983; 24:438.

38. Okuno T, Ito M, Nakano S dkk. Carbamazepine therapy and long-term prognosis in epilepsy of chldhood. Epilepsia 1989; 30:57-61 